\title{
ANALISIS EFEKTIVITAS DAN EFEK SAMPING PENGGUNAAN ANTIBIOTIK PADA PASIEN INFEKSI SALURAN KEMIH DI INSTALASI RAWAT INAP RSUP DR. WAHIDIN SUDIROHUSODO MAKASSAR
}

\author{
A. Rufaidah Hashary ${ }^{1}$, Marianti Manggau ${ }^{1}$, Hasyim Kasim ${ }^{2}$ \\ ${ }^{1}$ Fakultas Farmasi, Universitas Hasanuddin, Makassar \\ ${ }^{2}$ Fakultas Kedokteran, Universitas Hasanuddin, Makassar
}

Kata Kunci :

Infeksi Saluran Kemih, Antibiotik, Efektivitas, Efek Samping

\begin{abstract}
ABSTRAK
Infeksi saluran kemih dapat muncul sebagai beberapa sindrom yang terkait dengan respon inflamasi terhadap invasi mikroba dan dapat berkisar dari bakteriuria asimtomatik hingga pielonefritis dengan bakteremia atau sepsis. Pilihan lini pertama terapi antibiotik pada pasien infeksi saluran kemih adalah trimethoprim-sulfamethoxazole (TMP-SMX) dan atau golongan fluoroquinolone, lini kedua golongan nitrofurantion, dan lini ketiga golongan beta-laktam. Namun pada penelitian ini, antibiotik yang paling banyak digunakan adalah antibiotik beta-laktam golongan sefalosporin generasi ketiga yaitu ceftriaxone. Penelitian ini bertujuan untuk menganalisis efektivitas penggunaan obat antibiotik,interaksi antara obat antibiotik dengan obat lain, dan efek samping yang ditimbulkan dalam pemberian antibiotik pada pasien ISK dalam mengurangi infeksi pada pasien ISKdi RSUP Dr. Wahidin Sudirohusodo Makassar. Data yang diperoleh diuji deskriptif antara penggunaan antibiotik terhadap penurunan bakteri, WBC, dan neutrofil. Penggunaan dan dosis obat antibiotik pada pasien infeksi saluran kemih di instalasi rawat inap RSUP DR. Wahidin Sudirohusodo Makassar menunjukkan hasil yang efektif dalam mengurangi dan atau menyembuhkan infeksi saluran kemih. Efek samping yang terjadi setelah pemberian antibiotik ceftriaxone yaitu mual $9 \%$, nyeri perut $4,5 \%$, dan pemberian antibiotik ceftazidime mengalami diare $4,5 \%$. Interaksi yang terjadi pada pemberia antibiotik yaitu antara ceftriaxon dan furosemid, Penggunaan ceftriaxone (sefalosporin) bersamaan dengan furosemid (diuretik) dapat meningkatkan konsentrasi plasma atau menurunkan klirens dari ceftriaxon. Manajemen yang sebaiknya dilakukan adalah memonitoring fungsi ginjal.
\end{abstract}

\section{PENDAHULUAN}

Infeksi saluran kemih (ISK) merupakan infeksi bakteri yang paling umum. Menurut Survei Perawatan Medis Ambulatory National Hospital, infeksi saluran kemihterjadisekitar 1 juta kunjungan di gawat darurat, mengakibatkan 100.000 orang dirawat di rumah sakit (1). Saluran kemih manusia merupakan organ yang bekerja untuk mengumpul dan menyimpan urin dan organ yang mengeluarkan urin dari tubuh yaitu ginjal, ureter, kandung kemih dan uretra. Infeksi saluran kemih dapat menyerang pasien dari segala usia mulai bayi baru lahir hingga orang tua (2). Infeksi saluran kemih adalah salah satu penyakit infeksi dimana jumlah bakteriuria berkembang biak dengan jumlah kuman biakan urin lebih dari $100.000 / \mathrm{ml}$ urin. Bakteriuria asimtomatik didefinisikan sebagai kultur urin positif tanpa keluhan, sedangkan bakteriuria simtomatik didefinisikan sebagai kultur urin positif disertai keluhan (3).

Mikroorganisme penyebab ISK terbanyak adalah Escherichia coli yang ditemukan sekitar 70\%-95\% kasus dan Staphylococcus saprophyticus sekitar 5\%-10\% kasus (4). Berdasarkan pengalaman pada hari ke-7, ada sekitar $15 \%$ sampai $20 \%$ perbedaan respon klinis infeksi saluran kemih yang memerlukan rawat inap yang disebabkan oleh Escherichia coli (5).

Beberapa sifat ideal dariantibiotik yang dipilih untuk pengobatan infeksi saluran kemih yaitu dapat diabsorpsi dengan baik, ditoleransi oleh pasien, dapat mencapai kadar yang tinggi dalam urin, serta memiliki spektrum terbatas untuk mikroba yang diketahui atau dicurigai. Didalam saluran kemih juga sangat penting untuk mempertimbangkan peningkatan resistensi E. coli dan patogen lain terhadap beberapa antibiotik. Resistensi E. coli terhadap amoksisilin dan antibiotik sefalosporin diperkirakan mencapai $30 \%$. Patogen penyebab infeksi saluran kemih secara keseluruhan masih sensitif terhadap kombinasi trimetoprim-sulfametoksazol walaupun kejadian resistensi di berbagai tempat telah mencapai $22 \%$. Pemilihan antibiotik harus memperhatikan riwayat antibiotik yang digunakan pasien (6).

Studi yang telah dilakukan di Indonesia selama 1990-2001 menyatakan bahwa resistensi terjadi hampir pada semua bakteri-bakteri patogen penting. Hal tersebut merupakan dampak negatif dari penggunaan antibiotik yang tidak rasional, indikasinya tidak jelas, dosis atau lama pemakaian tidak sesuai, cara pemakaian kurang tepat, status obat yang tidak jelas, serta pemakaian antibiotik secara berlebihan (7). Kegagalan pengobatan biasanya disebabkan oleh organisme yang resisten, kelainan yang tidak terduga dari saluran kemih atau infeksi ulang dengan organisme serupa (8). pemilihan antibiotik untuk pengobatan infeksi 
Kegagalan pengobatan dapat pula disebabkan oleh ketidakefektivan pemilihan obat, lama pemakaian obat, dosis obat, kepatuhan pasien dalam mengkonsumsi obat antibiotik dan adanya interaksi obat. Kegagalan pengobatan pada pasien kemungkinan terjadinya interaksi dan efek samping obat cukup besar, terutama pada pasien yang mengkonsumsi lebih dari 5 macam obat pada saat yang bersamaan (9).

Pilihan utama terapi antibiotik pada pasien infeksi saluran kemih adalah trimethoprim-sulfamethoxazole (TMP-SMX) dan atau golongan fluoroquinolone, lini kedua golongan nitrofurantion, dan lini ketiga golongan beta-laktam. Beberapa antibiotik (golongan pinisilin) memiliki tingkat resistensi yang tinggi, sehingga tidak digunakan untuk penggunaan empiris (10).

Menurut penelitian Jabbar (2017) (11), yang dilakukan pada pasien infeksi saluran kemih di ruang rawat inap Rumah Sakit Universitas Hasanuddin menunjukkan bahwa obat antibiotik yang paling banyak diresepkan berdasarkan perhitungan Defined Daily Dose adalah ciprofloxacin 56, levofloxacin 38, ceftriaxone 34 , cefixime 12 , cotrimoxazole 5 , cefotaxime 4 , dan gentamicin 2. Hal ini telah sesuai dengan pilihan utama pengobatan namun efektivitas dan efek samping berdasarkan dosis dan lama penggunaan obat serta interaksi obat belum pernah diteliti.

\section{METODE PENELITIAN}

\section{Rancangan Penelitian}

Jenis penelitian ini merupakan penelitian dengan desain metode Kohort. Penelitian bersifat prospektif karena data yang diambil merupakan data assesmen pasien di Rumah Sakit Umum Pusat (RSUP) Dr. Wahidin Sudirohusodo.

\section{Waktu dan Lokasi Penelitian}

Waktu penelitian dilaksanakan pada periode bulan april sampai bulan juni 2018 dan lokasi penelitian dilaksanakan di RSUP Dr. Wahidin Sudirohusodo Makassar.

\section{Bahan dan Alat Penelitian}

Bahan dan alat dalam pegumpulan data pada penelitian ini menggunakan rekam medik pasien infeksi saluran kemih yang mendapatkan pengobatan antibiotik serta kelengkapan data pasien seperti usia, riwayat penyakit, pemeriksaan fisik penunjang lainnya, dan wawancara langsung dengan pasien.

\section{Populasi dan Sampel}

Populasi pada penelitian ini adalah pasien infeksi saluran kemih yang dirawat di instalasi rawat inap RSUP Dr. Wahdirohusodo Makassar. Populasi yang diperoleh sejak bulan April 2018 sampai Juni 2018 diperoleh 22 pasien yang memenuhi criteria inklusi. Sampel untuk penelitian ini adalah pasien infeksi saluran kemih yang mendapat terapi antibiotik yang dirawat di instalasi rawat inap RSUP Dr. Wahdirohusodo Makassar berdasarkan atas pertimbangan dan sesuai dengan kriteria inklusi dan ekslusi.

Adapun dengan kriteria inklusi penelitian ini adalah (1) Pasien rawat inap yang didiagnosis infeksi saluran kemih oleh dokter di RSUP Dr. Wahidin Sudirohusodo Makassar, (2) Pasien yang mendapat terapi antibiotik, (3) Pasien laki-laki dan perempuan $\geq 17$ tahun, (4) Bersedia menjadi subjek penelitian, dan (5) Pasien yang memiliki data rekam medik yang lengkap.

\section{Analisis dan Penyajian Data}

Pengolahan data hasil pemberian antibiotik pada pasien infeksi saluran kemih diuji secara deskriptif.
Ditinjau dari jenis kelamin, terlihat bahwa pasien yang mengalami infeksi saluran kemih pada laki-laki sebanyak 12 pasien (54\%) lebih banyak dibanding pasien perempuan sebanyak 10 pasien (46\%) (Tabel 1). Menurut penelitian Pratiwi (2013), yang menunjukkan hasil penelitian yang sama yakni penderita infeksi saluran kemih berdasarkan jenis kelamin laki-laki lebih bayak (55,7\%) dibanding perempuan $(44,3 \%)$. Perempuan lebih sering terkena ISK daripada laki-laki karena secara anatomis uretra wanita lebih pendek sehingga bakteri lebih mudah mencapai kandung kemih. Hal tersebut kemungkinan disebabkan oleh struktur anatomi perempuan yang memiliki uretra yang pendek sehingga mikroorganisme dari luar lebih mudah mencapai kandung kmih yang letaknya dekat dengan anus (12). Dibandingkan dengan laki-laki disamping uretranya lebih panjang juga dikarenakan adanya cairan prostat yang memiliki sifat bakterisidal sebagai pelindung terhadap infeksi bakteri (13). Penyebab infeksi saluran kemih pada pria yang paling sering terjadi adalah prostatitis atau hyperplasia prostat. Infeksi saluran kemih pada laki-laki juga biasanya disebabkan adanya kelainan anatomi, batu saluran kemih, atau penyumbatan pada saluran kemih (12).

\begin{tabular}{cccc}
\multicolumn{3}{l}{ Tabel 1. Karakteristik Pasien Infeksi Saluran Kemih } \\
\hline Karakteristik & $\begin{array}{c}\text { Variasi } \\
\text { kelompok }\end{array}$ & $\begin{array}{c}\text { Jumlah } \\
\text { pasien (n) }\end{array}$ & $\begin{array}{c}\text { Persentase } \\
\text { (\%) }\end{array}$ \\
\hline \multirow{2}{*}{ Jenis kelamin } & Laki-laki & 12 & 54 \\
& Perempuan & 10 & 46 \\
Pendidikan & SLTP & 7 & 32 \\
& SLTA & 10 & 45 \\
& S1 & 5 & 23 \\
Usia & $14-30$ & 3 & 14 \\
& $31-50$ & 12 & 54 \\
& $51-90$ & 5 & 23 \\
Penyakit & $71-90$ & 2 & 9 \\
penyerta & CKD + HT & 11 & 50 \\
& Hipertropi & 2 & 9 \\
& prostat & 9 & 41 \\
\hline
\end{tabular}

Berdasarkan pendidikan, subyek SLTP sebanyak 7 pasien (32\%), SLTA sebanyak 10 pasien (45\%), dan S1 sebanyak 5 pasien $(23 \%)$. Dari data tersebut menunjukkan bahwa pendidikan yang paling banyak menderita ISK dari tingkat SLTA kemudian SLTP dan selanjutnya S1. Tingkat pendidikan yang rendah, kemungkinan disebabkan karena kurangnya pengetahuan terhadap kesehatan dan sulit atau lambat menerima informasi (penyuluhan) yang diberikan oleh petugas sehingga berdampak pada perilaku/pola hidup sehat. Penderita yang memiliki pendidikan yang lebih tinggi akan mempunyai pengetahuan yang lebih luas juga memungkinkan pasien itu dapat mengontrol dirinya dalam mengatasi masalah yang dihadapi, rasa percaya diri yang tinggi, berpengalaman, mempunyai perkiraan yang tepat bagaimana mengatasi kejadian, mudah mengerti tentang apa yang dianjurkan oleh petugas kesehatan.

Berdasarkan usia, diperoleh usia terbanyak yang menderita infeksi saluran kemih adalah kelompok usia 31 tahun sampai 50 tahun sebanyak 12 orang (54\%), diikuti oleh kelompok usia 51 tahun sampai 70 tahun sebanyak 5 orang (23\%), kemudian usia 14 tahun sampai 30 tahun sebanyak 3 orang (14\%), dan pada usia 71 tahun sampai 90 tahun sebanyak 2 orang (9\%) (Tabel 1). Hal ini mungkin dikarenakan pada usia antara 16-35 tahun adalah yang berkitan dengan hubungan seksual. Morbiditas dan mortalitas ISK paling tinggi pada usia $<1$ tahun dan $>65$ tahun (14). Angka kejadian ISK meningkat seiring bertambahnya usia. Infeksi saluran kemih sering muncul pada orang-orang yang lebih tua baik dalam komunitas maupun dalam perawatan jangka panjang. Sejumlah faktor predisposisi yang mengakibtkan ISK pada 
orang yang lebih tua, antara lain penyakit prostat pada pria dan defisiensi estrogen post menopause pada perempuan (15). Terjadinya ISK pada usia lanjut dikarenakan pada usia lanjut terjadi penurunan daya tahan tubuh yang mengakibatkan system imun menjadi kurang efektif, selain itu, faktor lainya adalah perubahan sistem perkemihan yang menyebabkan pengosongan kandung kemih menjadi kurang efektif sehingga urin yang berada di kandung kemih dapat menyebabkan infeksi (16).

Berdasarkan penyakit penyerta yang diderita oleh pasien infeksi saluran kemih, persentase tertinggi terdapat 11 pasien $(50 \%)$ dengan CKD $+\mathrm{HT}$, kemudian 8 pasien $(41 \%)$ dengan diabetes, dan 2 pasien (9\%) dengan hipertropi prostat (Tabel 1). Hipertensi merupakan salah satu penyebab CKD melalui suatu proses yang mengakibatkan hilangnya sejumlah besar nefron fungsional yang progresif dan irreversible. Peningkatan tekanan dan regangan yang kronik pada arteriol dan glomeruli diyakini dapat menyebabkan sklerosis pada pembuluh darah glomeruli atau yang sering disebut degan glomerulosklerosis (17). Salah satu komplikasi CKD adalah gangguan imunologis. Pasien penderita CKD, fungsi imunologis terganggu dan infeksi sering terjadi. Kejadian infeksi yang tinggi dijumpai pada penderita uremik. Uremia menekan fungsi sebagian besar sel imun penderita. Adanya komplikasi imunologis menyebabkan penderita CKD lebih mudah terkena infeksi dibandingkan orang normal. Penderita CKD mudah terkena infeksi seperti infeksi saluran kemih (18).

Infeksi saluran kemih pada pasien diabetes menurut beberapa hasil penelitian disebabkan berbagai faktor risiko. Faktor-faktor risiko infeksi saluran kemih pada pasien diabetes yaitu usia, lama menderita diabetes, indeks massa tubuh, hubungan seksual dan upaya pengendalian diabetes. Infeksi saluran kemih pada pasien diabetes umumnya terjadi pada pasien dengan pengendalian diabetes yang buruk dan adanya infeksi dapat memperburuk pengendalian glukosa darah (19). Gejala infeksi saluran kemih pada pasien diabetes umumnya asimtomatik, namun dapat berkembang menjadi simtomatik dan meningkatkan risiko untuk masuk rumah sakit dengan bakteremia hingga pielonefritis bilateral. Oleh karena itu, walaupun gejala infeksi saluran kemih pada pasien diabetes asimtomatik hal ini tidak dapat diabaikan (20).

Antibiotikyang digunakan untuk terapi pasien infeksi saluran kemih pada penelitian ini terdiri dari 7 macam antibiotik dengan 6 golongan antibiotik. Penggunaan ceftriaxone mencapai setengah dari jumlah pasien dengan persentase $50 \%$, kemudian meropenem 23\%, amikasin 9\%, metronidazole $5 \%$, levofloxacin $5 \%$, clindamysin $4 \%$, dan yang terakhir ceftazidime $4 \%$. Antibiotik yang biasa digunakan dalam pengobatan infeksi saluran kemih adalah cotrimoxazole, fluoroquinolone, $\beta$-laktam (penicillin, sefalosporin, dan karbapenem, dan monobaktam) (21).

Kelompok penggunaan obat antibiotik yang paling banyak pada penelitian ini disimpulkan sebesar $50 \%$ pada panggunaan ceftriaxon. Ceftriaxon adalah antibiotik golongan sefalosporin generasi ketiga yang memiliki spektrum antibakteri yang lebih luas dibanding generasi sebelumnya dan aktif terhadap bakteri gram negatif yang telah resisten, lebih tahan terhadap beta laktamase, tetapi kurang aktif terhadap bakteri gram positif (22).

Mekanisme kerja sefalosporin (ceftriaxon) sebagai antimikroba yaitu dengan menghambat sintesis dinding sel bakteri, dimana dinding sel tersebut berfungsi untuk mempertahankan bentuk mikroorganisme dan "menahan" sel bakteri, yang memiliki tekanan osmotik yang tinggi di dalam selnya. Tekanan di dalam sel pada bakteri gram positif 3-5 kali lebih besar daripada bakteri gram negatif. Kerusakan pada dinding sel atau hambatan pembentukannya dapat mengakibatkan lisis pada sel (23).

Ceftriaxon merupakan antibiotik yang secara luas digunakan untuk mengobati infeksi umum seperti pneumonia dan infeksi saluran kemih karena ceftriaxon diekskresikan melalui ekskresi bilier dan ginjal, pasien dengan gagal ginjal tidak memerlukan penyesuaian dosis (24). Durasi pemberian ceftriaxon minimal 3 hari. Pemberian ceftriaxon (sefalosporin) pada pasien dengan kerusakan fungsi ginjal dah hati, kadar sefalospoin dalam darah sebaiknya dimonitor dan dilakukan penyesuaian dosis. Dosis tidak boleh lebih dari $2 \mathrm{~g} / \mathrm{kg}$ BB per hari. Dosis seftriaxon pada gangguan ginjal berat maksimal 2 gram sehari (25). Dosis pemberian ceftriaxone pada penelitian ini sudah sesuai dengan literatur, dimana ceftriaxone diberikan dengan dosis 2 gram per hari.

Meropenem merupakan antibiotik kelas terbaru yang digunakan apabila sudah resisten terhadap antibiotika betalaktam dan golongan sefalosporin. Antibiotik golongan karbapenem ini efektif digunaka untuk mengobati infeksi yang disebabkan oleh bakteri gram negative penghasil ESLB (extended spectrum beta-lactamase), sehingga meropenem efektif digunakan pada bakteri yang resisten terhadap betalaktam. Dosis pemberian meropenem $500 \mathrm{mg}$ hingga $1 \mathrm{~g}$ per hari. Penanganan awal untuk pengobatan meropenem dalam jangka waktu 5 hari dan dapat diperpanjang selama 7 hari kemudian dilakukan pemeriksaan laboratorium (26).

Data deskriptif menunjukkan hasil yang efektif dalam mengurangi dan atau menyembuhkan infeksi saluran kemih (Tabel 2). Bakteri patogen adalah bakteri yang mampu menyebabkan penyakit. Bakteri patogen dapat menyebar melalui populasi manusia dalam berbagai cara. Pengobatan infeksi yang disebabkan bakteri patogen melibatkan penggunaan antibiotik, obat yang telah diformulasikan khusus untuk membunuh bakteri (27).

\begin{tabular}{ccccc}
\multicolumn{5}{lc}{ Tabel 2. Hasil Analisis Terapi Antibiotik Ceftriaxone dan Meropenem } \\
\hline \multicolumn{5}{c}{ Hasil analisis terapi Ceftriaxone } \\
\hline Parameter & Sebelum & Sesudah & Selisih & $\begin{array}{c}\text { Persentase } \\
\text { penurunan } \\
\text { (\%) }\end{array}$ \\
\hline Bakteri & 1291 & 629 & 662 & 51,28 \\
WBC & 272,35 & 123,46 & 148,89 & 54,67 \\
Neutrofil & 891,2 & 753,2 & 138 & 15,48 \\
\hline \multicolumn{5}{c}{ Hasil analisis terapi Meropenem } \\
\hline Bakteri & 694 & 121 & 573 & 82,56 \\
WBC & 85,49 & 36,85 & 48,64 & 56,89 \\
Neutrofil & 442 & 362 & 80 & 18,57 \\
\hline \multicolumn{5}{c}{}
\end{tabular}

Leukosit paling sedikit dalam tubuh jumlahnya sekitar 4.000$11.000 / \mathrm{mm}^{3}$. Berfungsi untuk melindungi tubuh dari infeksi. Karena itu, jumlah leukosit tersebut berubah-ubah dari waktu ke waktu, sesuai dengan jumlah benda asing yang dihadapi dalam batas-batas yang masih dapat ditoleransi tubuh tanpa menimbulkan gangguan fungsi. Meskipun leukosit merupakan sel darah, tapi fungsi leukosit lebih banyak dilakukan di dalam jaringan. Leukosit hanya bersifat sementara mengikuti aliran darah ke seluruh tubuh. Apabila terjadi peradangan pada jaringan tubuh leukosit akan pindah menuju jaringan yang mengalami radang dengan cara menembus dinding kapiler (28).

Hasil pengamatan dari efek samping yang ditimbulakan setelah pemberian antibiotik pada pasien infeksi saluran kemih terdapat beberapa pasien yang mengalami diare, nyeri perut, dan mual. Efek samping yang biasa timbul akibat penggunaan ceftriaxon diantaranya dermatologi (ruam), gastrointestinal (diare), hematologi (eosinofilia, trombositosis, dan leucopenia), hepatik (transaminase meningkat), lokal (alergi di tempat suntikan dan nyeri), dan renal (BUN meningkat) (25). 
Reaksi yang tidak diinginkan dalam penggunaan obat antibiotik meropenem yaitu kardiovaskular (gangguan embuluh darah perifer), sistem saraf pusat (sakit kepala dan nyeri), dermatologi (ruam dan pruritus), endokrin dan metabolic (hipoglikemia), gastrointestinal (diare, mual/ muntah, konstipasi, moniliasis oral, dan glositis), hematologi (anemia), lokal (peradangan di tempat suntik dan reaksi alergi pada tempat suntukan), pernafasan (apnea, faringitis, dan pneumonia), dan miscellaneous (sepsis, dan syok) (25).

Interaksi antara ceftriaxon dan furosemid disarankan untuk dikelola dengan penyesuaian dosis dan pemantauan untuk reaksi yang merugikan terhadap obat penyerta. Penggunaan ceftriaxon (sefalosporin) bersamaan dengan furosemid (diuretic) dapat meningkatkan konsentrasi plasma atau menurunkan klirens dari ceftriaxon. Manajemen yang dilakukan adalah memonitoring fungsi ginjal (29). Interaksi ini merupakan interaksi obat secara farmakokinetik pada proses metabolism dimana kadar ceftriaxon dalam pasma meningkat karena enzim pemetabolismenya sama di CYP 450 dan dikarenakan terjadi kompetisi untuk sekresi aktif ditubulus ginjal yang dapat menyebabkan hambatan sekresi sehingga terjadi penurunan klirens pada ceftriaxone.

\section{KESIMPULAN}

Penggunaan dan dosis obat antibiotik pada pasien infeksi saluran kemih di instalasi rawat inap RSUP DR. Wahidin Sudirohusodo Makassar menunjukkan hasil yang efektif dalam mengurangi dan atau menyembuhkan infeksi saluran kemih. Efek samping yang terjadi setelah pemberian antibiotik ceftriaxone yaitu mual $9 \%$, nyeri perut $4,5 \%$, dan pemberian antibiotik ceftazidime mengalami diare $4,5 \%$. Interaksi yang terjadi pada pemberia antibiotik yaitu antara ceftriaxon dan furosemid, Penggunaan ceftriaxone (sefalosporin) bersamaan dengan furosemid (diuretik) dapat meningkatkan konsentrasi plasma atau menurunkan klirens dari ceftriaxon. Manajemen yang sebaiknya dilakukan adalah memonitoring fungsi ginjal.

\section{UCAPAN TERIMA KASIH}

Penulis mengucapkan terima kasih kepada Allah Subhanahuwata'ala, kedua orang tua, pembimbing dan terima kasih pula kepada Fakultas Farmasi Universitas Hasanuddin.

\section{DAFTAR PUSTAKA}

1. Foxman, B. 2002. Epidemiology of Urinary Tract Infections: Incidence, morbidity, and Econimoc Costs. Department of Epidemiology, University of Michigan School of Public Health, Ann Arbor, Michigan, USA.

2. Sukandar E. 2006. Buku Ajar Ilmu Penyakit Dalam Jilid I. Jakarta: Balai Penerbit FK UI. 564-8.

3. Kahlmeter G. 2003. An International Survey of the Antimicrobial Susceptibility of Pathogens from Uncomplicated Urinary Tract Infections. J Antimicrob Chemother. 51(1): 69-76.

4. Bartoletti, R., Cai, T., Wagenlehner, FM., Naber, K., Johansen, TEB. 2016 Treatment of Urinary Tract Infection and Antibiotik Stewardship. European Association of Urology.

5. Palau, EE., Solande, G., Sanchez, F., Sorli, L., Montero, M., Guerri, R., Villar, j., Grau, S., Horcajada, JP. 2015. Clinical and economic impact of urinary tract Infections caused by ESBL-producing Escherichia coli requiring hospitalization: a matched cohort study. Barcelona, Spain. DOI: 10.1016/j.jinf.2015.08.012

6. Coyle, E. A., dan Prince, R, A., 2005, Urinary Tract Infection and Prostatitis, in Dipiro J, T., et al., (Eds.), Pharmacotherapy: A pathophysiologic Appoach.5th Edition, The Mc Gpaw Hill Companies, Inc, USA.

7. Lestari, E.S., Severin, J.A., Filius, P.M., Kuntaman, K, Duerink, D.O., Hadi, U., Wahjono, H., Verbrugh, H.A. 2008. Antimicrobial Resistance in Indonesia: Prevalence and Prevalantion (AMRIN). Antimicrobial resistence among commensal isolates of Escherichia coli and Staphylococcus aureus in the Indonesian population inside and outside hospitals. Eur J Clin Microbiol Infect Dis.

8. National Drugs and Therapeutics Subcommittee (NDTS). 2011 Antibiotik Guidelines 3 ${ }^{\text {rd }}$ Edition. Ministry of Health Government of Fiji.

9. Dalimunthe, A. 2009. Interaksi Pada Obat Antimikroba. Departemen Farmakologi. Medan.

10. Dipiro, J.T., Talbert, R.L., Yee, G.C., Matzke, G.R., Wells, B.G., and Posey, L.M 2008. Pharmacotherapy A Pathophysiologic Approach; Seventh Edition, McGraw-Hill Education. USA. America.

11. Jabbar, H. 2017. Evaluasi Penggunaan Antibiotika dengan Metode DDD (Defined Daily Dose) pada Penderita Infeksi Saluran Kemih di Rumah Sakit Universitas Hasanuddin Periode 2016. Fakultas Farmasi UNHAS, Makassar.

12. Smeltzer, S.C.,\& Bare, B.G. 2002. Buku ajar keperawatan medical bedah brunner \& suddarth Edis 8.

13. Sholihah Alfi Hidayatus, analisis factor risiko kejadian infeksi saluran kemih (ISK) oleh bakteri uropatogen di puskesmas ciputat dan pamulang pada agustus - oktober 2017. Program studi kedokteran dan profesi dokter fakultas kedokteran dan ilmu kesehaan universitas islam negeri syarif hidayatullah Jakarta.

14. Nguyen HT. 2004. Bacterial Infection of The Genitourinary Tract. Smith's General Urology 16th ed. USA: The McGraw Hill Companies. 203-27.

15. Beveridge L, Davey PG, Phillips G, McMurdo MET. 2016. Optima management of urinary tract infection in older people. Dovepress journal.

16. Pratiwi, Dini surya. 2013. Kajian uji resistensi dan sensitivitas antibiotik ceftriaxon dan cifrofloxacin pada penderita infeksi saluran kemih dir sup fatmawati. Fakultas kedokteran dan ilmu kesehatan program study farmasi universitas islam negeri syarif hidayatullah. Jakarta.

17. Guyton, A.C., and Hall, J.E., 2008. Buku Ajar Fisiologi Kedokteran. 11th ed, Jakarta: EGC, pp. 231-237 dan 326-327.

18. Hapsari AP. 2012. Perbedaan leukosituri antara penderita penyakit ginjal kronik stadium 5 dengan diabetes melitus dan tanpa diabetes melitus. Skripsi. Fakultas Kedokteran Universitas Diponegoro, Semarang.

19. PERKENI. 2011. Konsensus Pengelolaan dan Pencegahan Diabetes Melitus Tipe 2 di Indonesia. Jakarta: PERKENI.

20. Saleem M. \& Daniel, B. 2011. Prevalence of urinary tract infection among patients with diabetes in Bangalore City. International Journal of Emerging. Sciences.

21. Syarif, Amir. 2007. Farmakologi dan Terapi edisi 5, Fakultas Kedokteran Universitas Indonesia, Jakarta.

22. Siswandono, 2008. Mikia medicinal edisi 2. Surabaya: airlangga university press

23. Mycek MJ, Harvey RA, Champe PC. 2001. Farmakologi Ulasan Bergambar. Jakarta: Widya Medika.

24. Inoue, Y. Doi, Y. arisato, t. sugioka, s. koga, k. nishioka, k. and sugawara, a 2017. Three cases of hemodialysis patients receiving high-dose ceftriaxone: serum concentrations and its neurotoxicity. Department of nephrology, Osaka red cross hospital, Osaka, japan.

25. Aberg, J.A., Lacy, C.F, Amstrong, L.L, Goldman, M.P, and Lance, L.L., 2009, Drug Information Handbook, 17th edition, Lexi-Comp for the American Pharmacists Association.

26. Rosso-fernandoz, Sojo-dorado J, Barriga A. 2015. Fosfomycin versus meropenem in bacteraemic urinary tract infections caused by extendedspectrum B-lactamase-producing Escherichia coli (FOREST): study protocol for an investigator-driven randomized controlled trial. BMJ Open. doi:10.1136/bmjopen-2014-007363.

27. Hanafiah dan Kemas Ali. 2005. Biologi Tanah, Ekologi dan Mikrobiologi Tanah. Jakarta: Raja Grafindo Persada.

28. Kiswari, Rukman. 2014. Hematologi dan Transfusi. Jakarta: Erlangga

29. Bhatt, D., Shah, A., Yadav, D.K., Shah, A.K., Mahesh., Ravichander., Alex, V. 2017. Prescribing Pattern and Cost Analysis of B-Lactam Antibiotics in Rural Pediatric Patient: A Prospective Observational Study. 